\title{
Rare Earth Element and Rare Metal Inventory of Central Asia
}

Rare earth elements (REE), with their unique physical and chemical properties, are an essential part of modern living. REE have enabled development and manufacture of high-performance materials, processes, and electronic technologies commonly used today in computing and communications, clean energy and transportation, medical treatment and health care, glass and ceramics, aerospace and defense, and metallurgy and chemical refining. Central Asia is an emerging REE and rare metals (RM) producing region. A newly compiled inventory of REE-RMbearing mineral occurrences and delineation of areas-of-interest indicate this region may have considerable undiscovered resources.

\section{The Silk Road and REE-RM}

Central Asia, situated along the historic "Silk Road" trade route, has long been a network for the movement and transportation of people, energy, and mineral resources between Europe and Asia. Once part of the former Soviet Union, this region historically produced rare earth elements (REE), and is still an important source of base and precious metals, as well as rare metals (RM).

Today, central Asia is re-emerging as a REE-producing region. In the countries of Kazakhstan, Kyrgyzstan, and Tajikistan, there has been renewed interest in REE (and related RM), particularly following the REE price run-ups in 2007 and 2009, and a dramatic price spike in 2011. These countries have since implemented mining sector reforms to create a more attractive investment environment for domestic and foreign mineral exploration and economic development.

High-quality and readily accessible information about the geology and mineral resources of the region is essential for facilitating reforms, reducing economic risk, and stimulating private-sector interest. In 2012-13, the U.S. Geological Survey (USGS) conducted an evaluation of the REE-RM mineral resources of central
Asia, which included the development of a mineral occurrence inventory, and the study of related capacity and capacity-building needs of the region.

\section{Tectonic Setting}

The REE-RM-bearing mineral occurrences of central Asia are products of numerous magmatic, metamorphic, and sedimentary metallogenic (mineral-deposit forming) processes that took place during successive cycles of accretionary and extensional orogenesis (mountain building), and post-orogenic weathering, erosion, and deposition. Flanked by cratons and tectonic blocks of Precambrian age, the region consists of younger orogenic belts representing numerous continental and oceanic crustal fragments that were welded together during a complex and episodic history of subduction, accretion, arc- and continent-continent collisions, and ocean basin closures in Paleozoic and Mesozoic time (see Windley and others, 2007). Two of the largest of these belts are (1) the Paleozoic Central
Asian Orogenic Belt, which includes the Kazakh Steppe, Kazakh Uplands, and the Tien Shan Mountains of Kazakhstan, Kyrgyzstan, and easternmost Uzbekistan; and (2) the late Paleozoic to Mesozoic Tethys Orogenic Belt, the central and northern part of which includes the Pamir Mountains in Tajikistan.

\section{REE-RM Resources}

In a global context, domestic REE reserves are modest, accounting for about 10 percent of the world total (Gambogi, 2014). Currently the United States does not produce REE, but is a net importer, obtaining its REE raw materials from foreign sources, primarily from China. Over the past two decades, the importance of REE has increased markedly owing to (1) high demand for modern technologies and advanced materials, of which REE are integral components; (2) uncertain supply, given China's dominance of over 95 percent of global REE production; and (3) the unique electronic, optical, and

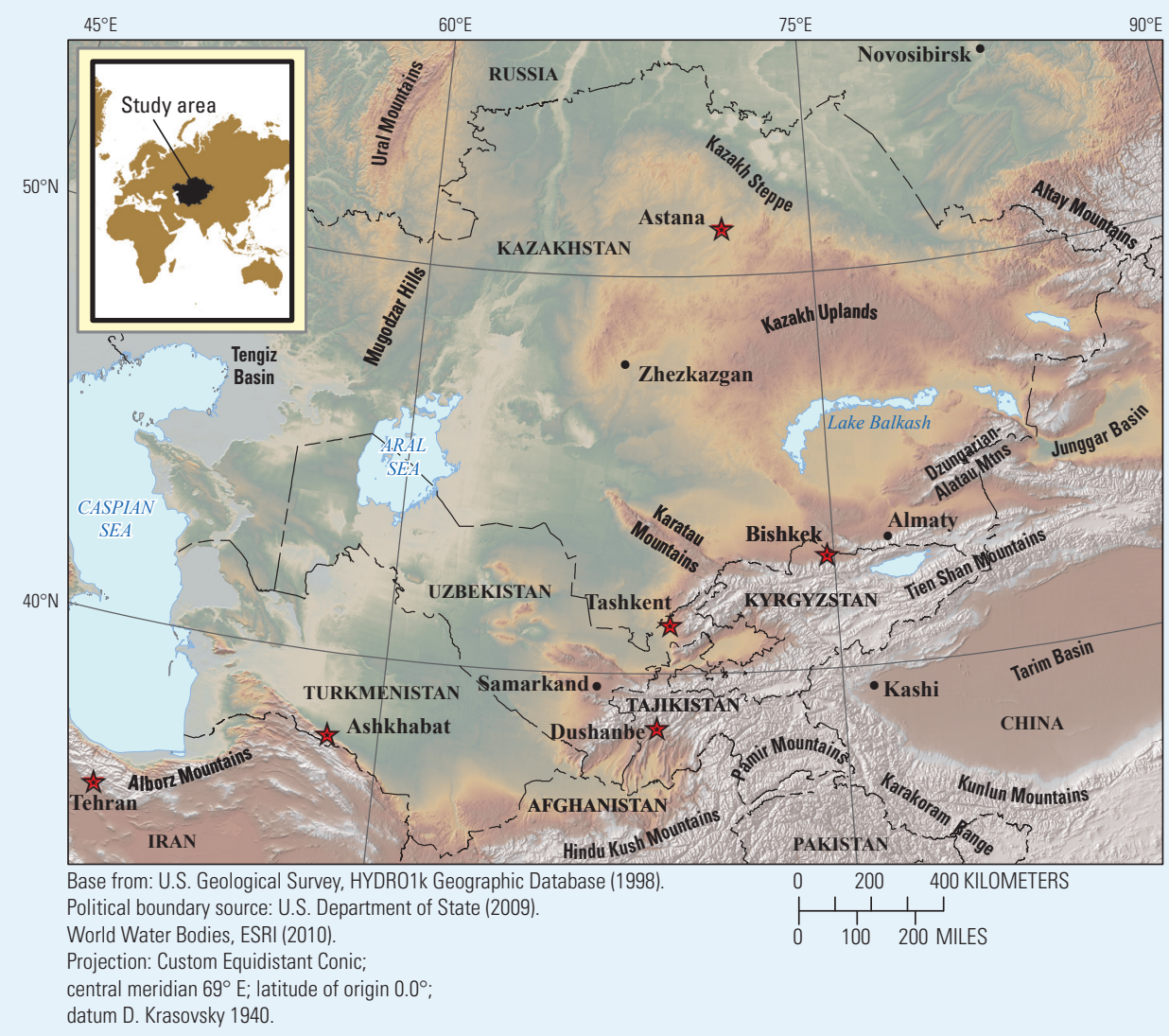

Map of central Asia, showing countries, capitals (red stars), larger cities (black dots), and major geographic features. 


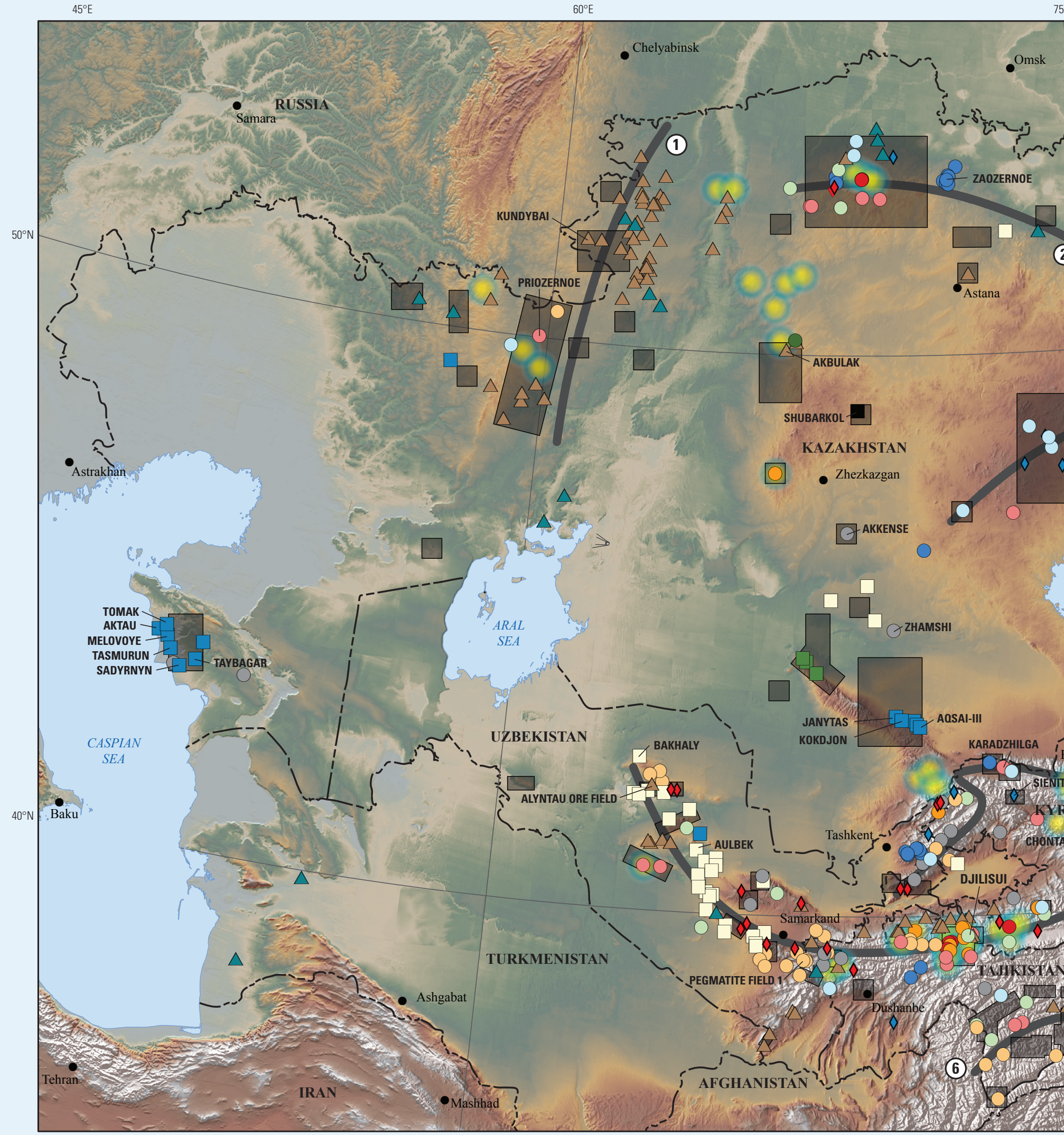

magnetic properties of REE, which cannot be matched in performance by other metals or synthetic materials (Long, 2011). These factors have raised international concern that new sources of REE outside of China must be identified, explored, and assessed for economic viability.

Central Asia is of significant interest for mineral exploration because it hosts known REE-RM-bearing mineral occurrences and is thought to have considerable undiscovered resources. The USGS has compiled an inventory of 384 occurrences in Kazakhstan (160 sites), Kyrgyzstan (75 sites), Tajikistan (60 sites), Uzbekistan (87 sites), and Turkmenistan (2 sites), which range from mineral showings to previously developed deposits (Mihalasky and others, 2017). The most important attributes recorded in the inventory include occurrence location, geologic setting, deposit type, size, associated commodities, grade, mineralogy, and age of mineralization.

The occurrences are associated with at least 16 different deposit types, among which 5 broad deposit-type classes are recognized: (1) igneous rock-related, (2) 


\section{EXPLANATION}

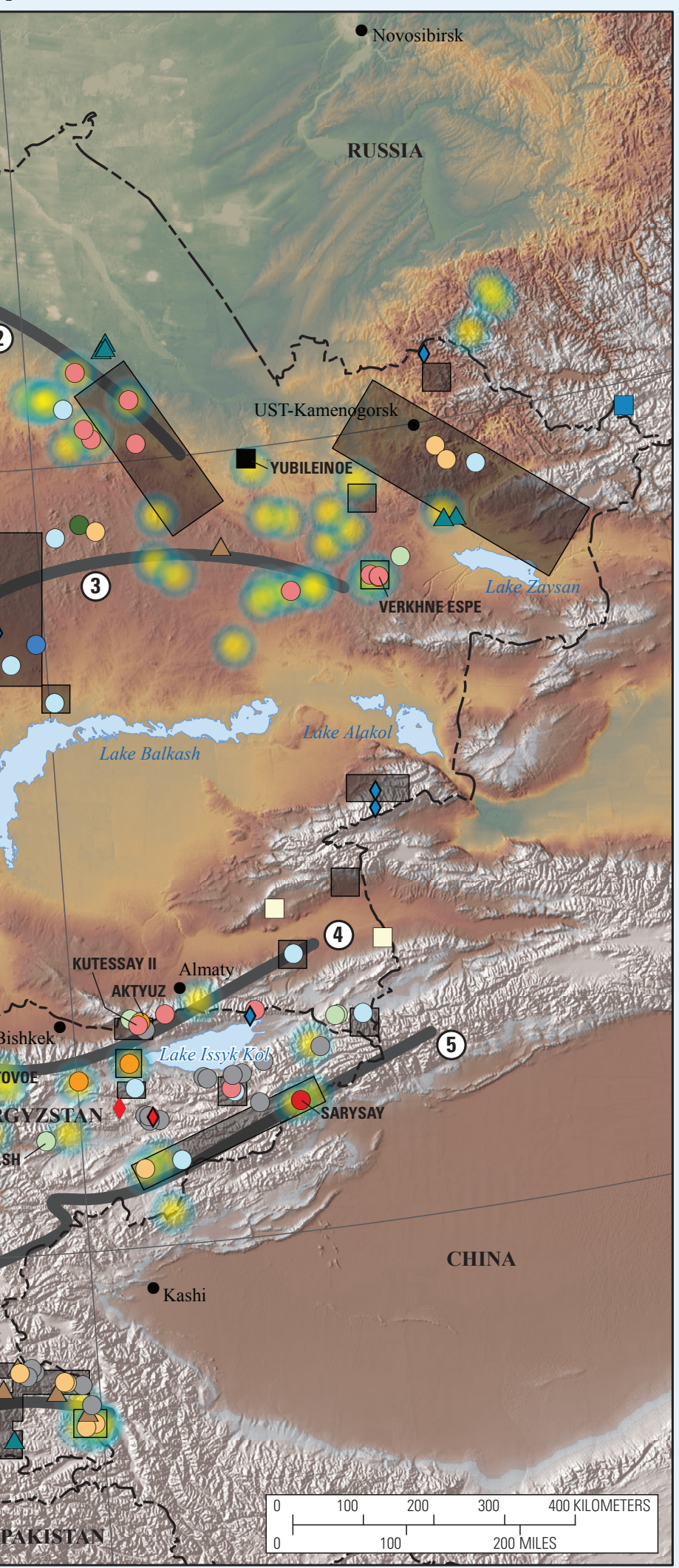

REE-RM-bearing mineral occurrences by deposit-type (deposits labled)

Igneous-related

Carbonatite

Peralkaline-related

Alkaline-related

Pegmatite

Granitoid-related

Volcanic/epithermal of uncertain affinity

Intrusive/mesothermal of uncertain affinity

Exhalative

Metamorphic/metasomatic-related

$\diamond$ Skarn

$\diamond$ Greisen

Sedimentary-related

$\square$ Sedimentary uranium

Sedimentary phosphate

- Sedimentary vanadium and(or) molybdenite

Coal

Surficial weathering/erosion-related

$\triangle$ Weathering crust

$\triangle$ Placer or paleoplacer

Uncertain

Deposit type unknown or unspecified

REE-RM mineral resource potential

Areas of intrest (Kazakhstan, Kyrgyzstan,

Tajikistan, and Uzbekistan only)

Alkaline igneous rock and carbonatite occurrences

REE-RM belts

(1) Uraltides

(2) Kazakh Steppe

(3) Kazakh Uplands

(4) North Tien Shan

(5) South Tien Shan

(6) Pamir

Base from: U.S. Geological Survey, HYDR01k Geographic Database (1998)

Political boundary source: U.S. Department of State (2009).

World Water Bodies, ESRI (2010).

Projection: Custom Equidistant Conic;

central meridian $69^{\circ} \mathrm{E}$; latitude of origin $0.0^{\circ}$

datum D. Krasovsky 1940.

Map of central Asia (Kazakhstan, Kyrgyzstan, Tajikistan, Uzbekistan, and Turkmenistan) showing rare earth element- and rare metal- (REE-RM) bearing mineral occurrences and areas-of-interest (AOI) for mineral resource potential. The 384 known REE-RMbearing occurrences include 16 deposit types, which are generalized into 5 broad classes. The $\mathrm{A} 0 \mathrm{I}$ represent (1) regions where alkaline igneous rocks and carbonatites are present (from Kogarko and others, 1995; these rock types are known to be closely associated with commercially important REE-RM-bearing deposits worldwide); and (2) prospective areas, promising occurrences, and known occurrences identified in State agency exploration reports and presentations provided by geoscientists from Kazakhstan, Kyrgyzstan, Tajikistan, and Uzbekistan at an REE-RM resources workshop, hosted by the U.S. Geological Survey, and held at the Kyrgyz National Academy of Sciences, Institute of Geology, on September 16-17, 2013, in Bishkek, Kyrgyzstan. The $\mathrm{AOI}$ represent mineral potential for all types of REE-RM-bearing occurrences. metamorphic/metasomatic-related, (3) sedimentary-related, (4) surficial weathering/erosion-related, and (5) uncertain. The most common host rocks recorded in the inventory are alkaline igneous rocks, their weathered derivatives, and metamorphic and metasomatic rocks. Occurrences associated with carbonatite and alkaline igneous rock-related deposit types generally display higher REE grades. The most commonly reported REE-RM-bearing minerals are monazite, zircon, apatite, xenotime, pyrochlore, allanite, and columbite. Ages of mineralization range from Cambrian through the Quaternary, with most occurrences falling within three broad intervals of geologic time: 570-408 Ma (late Proterozoic to early Paleozoic), 360-248
Ma (late Paleozoic to early Mesozoic), and $\sim 144-38 \mathrm{Ma}$ (late Mesozoic to early Tertiary).

\section{REE-RM Resource Potential}

In addition to developing an inventory of known occurrences, another principal objective of the USGS evaluation of 
REE-RM mineral resources in central Asia was to identify areas-of-interest (AOI) with potential for hosting undiscovered deposits (see center map caption for the definition of an AOI). Six REE-RM metallogenic belts containing AOI and REE-RM-bearing mineral occurrences have been delineated: (1) the Uraltides Belt, characterized primarily by weathered-crust occurrences, exemplified by the large Kundybai deposit; (2) the Kazakh Steppe Belt, defined by mainly peralkaline, carbonatite, and granitoid and other intrusive- and extrusive-related prospects and showings, as well as their associated metamorphic/metasomatic and surficial weathering occurrences; (3) the Kazakh Uplands Belt, dominated by peralkaline, granitoid, and other igneous rock-related and associated metamorphic/ metasomatic occurrences, including the peralkaline igneous rock-related Verkhne Espe deposit; (4) the North Tien Shan Belt, characterized by a wide variety of deposittypes, and which has the largest potential for commercial production from the Aktyuz cluster of deposits (this includes the peralkaline igneous rock-hosted Kutessay II deposit, a past-producer and supplier of heavy REE and RM to the former Soviet Union); (5) the South Tien Shan Belt, host to the greatest number and variety of occurrences and deposit-types, including peralkaline, granitoid, and other igneous rock-related prospects and showings in the east and east-central region of the belt, as well as pegmatite and sandstone-hosted uranium in the west and west-central region; and (6) the Pamir Belt, defined mainly by pegmatite, peralkaline igneous rock-related, and weathered-crust prospects and showings, including the Sungat granitoid-related prospect in the west, and the Agadjan and Agandzhan pegmatite prospects associated with Dunkeldyk and Pamir Pipes carbonatite complexes in the east.

\section{References Cited}

Gambogi, Joseph, 2014, Rare earths, in Mineral commodity summaries 2014: U.S. Geological Survey, p. 128-129.

Kogarko, L.N., Kononova, V.A., Orlova, M.P., and Woolley, A.R., 1995, Alkaline rocks of the world, part 2-Former Soviet Union: London, Chapman \& Hall, 226 p.

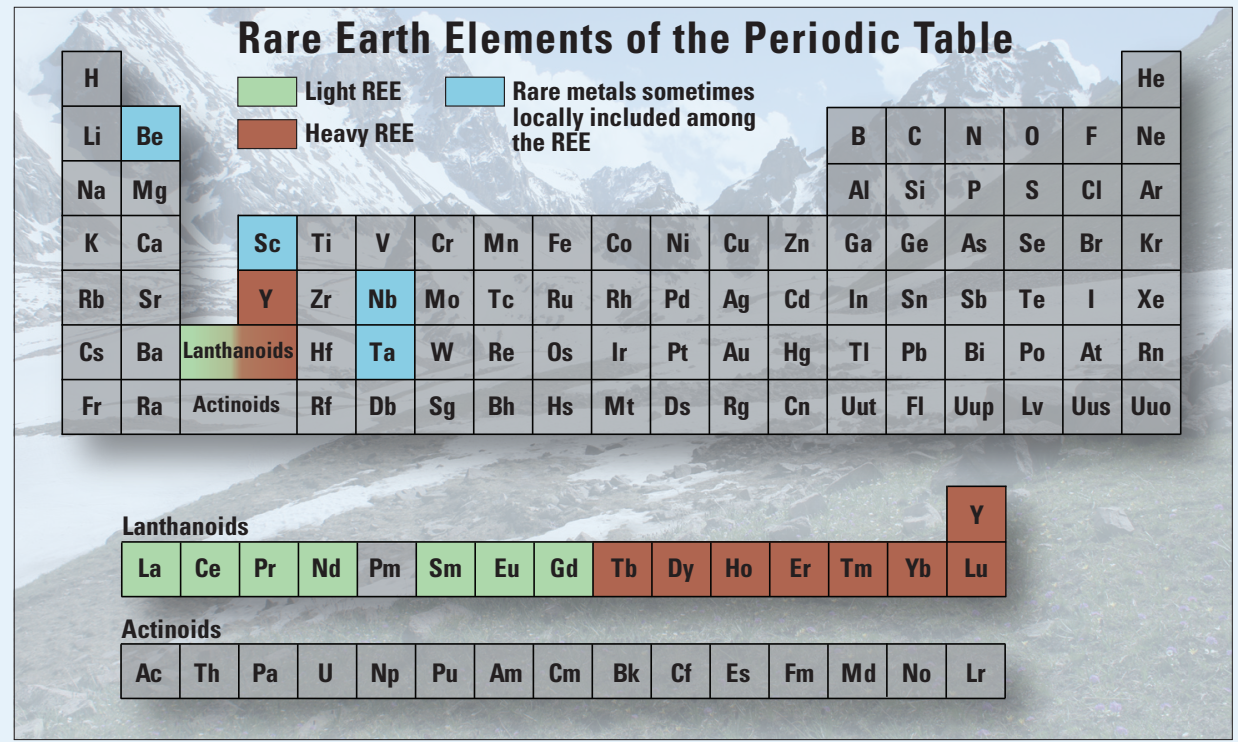

Periodic table of chemical elements, highlighting the rare earth elements (REE) and related rare metals, which are sometimes included among REE in central Asia.

Long, K.R., 2011, The future of rare earth elements-Will these high-tech industry elements continue in short supply?: U.S. Geological Survey Open-File Report 2011-1189, 41 p., available at http://pubs.usgs.gov/of/2011/1189/.

Mihalasky, M.J., Orris, G.J., Briggs, D.A., Tucker, R.D., Renaud, Karine, and Verstraeten, I.M., 2017, Rare earth element mineral occurrence database of the Tien Shan region, Central Asia: U.S. Geological Survey data release, available at https://doi.org/10.5066/ F7TM7913.

Windley, B.F., Alexeiev, D., Xiao, W., Kroner, A., and Badarch, G., 2007, Tectonic models for accretion of the Central Asia orogenic belt: London, Journal of the Geological Society, v. 164, p. 31-47.

\section{Additional Information}

Contact Dr. Mark J. Mihalasky (mjm@usgs.gov) and Dr. Ingrid M. Verstraeten (imverstr@usgs.gov) for additional information about this study and USGS activities in central Asia.

\section{Acknowledgments}

USGS Central Asia REE-RM Team: Mark J. Mihalasky, Robert D. Tucker, Karine Renaud, and Ingrid M. Verstraeten. This study was funded with Economic Support Funds (ESF) from the U.S. Department of State project: DOS-1010104105: Rare Earth Element (REE) Resources of the Tien Shan Region, Central Asia.

Contributors and cooperators: Kazakhstan-Ministry of Industry and New Technologies, Kazgeology, Kazgeology, Satpaev, Nazarbayev University; Kyrgyzstan - State Agency for Geology and Mineral Resources, National Academy of Sciences, Stans Energy KG LLC; Tajikistan-Head Department for Geology, National Academy of Sciences; EnglandCentre for Russian and Central EurAsian Mineral Studies.

Text prepared by Mark J. Mihalasky. Illustrations by John C. Wallis. Technical assistance for REE-RM data compilation from Deborah Ann Briggs.

The Kutessai II rare earth element-rare mineral (REE-RM) mineral deposit, northeast of Bishkek, in Kyrgyzstan, on May 29, 2013. The currently inactive mine is a Soviet-era openpit operation, approximately 1 kilometer wide and 300 meters deep.
Edited by Katherine Jacques Layout by Vivian Nguyen 